\title{
The Challenges Faced on Transit Transport Corridors by Landlocked Countries in Central Africa: Literature Review
}

\author{
Djasrabe Frederic ${ }^{*}$, Helai Huang, Chenghui Mao \\ Traffic and Transportation, CSU, Changsha, China \\ Email: ^belengarfrederic@yahoo.fr, huanghelai@csu.edu.cn,19117127@qq.com
}

How to cite this paper: Frederic, D., Huang, H.L. and Mao, C.H. (2021) The Challenges Faced on Transit Transport Corridors by Landlocked Countries in Central Africa: Literature Review. Open Journal of Applied Sciences, 11, 1200-1211.

https://doi.org/10.4236/ojapps.2021.1111090

Received: June 2, 2021

Accepted: November 14, 2021

Published: November 17, 2021

Copyright $\odot 2021$ by author(s) and Scientific Research Publishing Inc. This work is licensed under the Creative Commons Attribution International License (CC BY 4.0).

http://creativecommons.org/licenses/by/4.0/

\begin{abstract}
The landlocked countries are the one without access to the sea and can be assimilate as countries around the world with a disadvantage of geography situation location. Chad and the Central African Republic are two of the 40 landlocked countries around the world that transport $80 \%$ of their goods by road and rail, and as much as almost more than $50 \%$ of their passengers through a transit country with a transit transport system which is crucial for their trade and exchanges. The study aims to introduce the importance to have a good and efficiency transport network infrastructure in Central Africa to facilitate the trade for the landlocked countries of Central Africa (Chad and the Central African Republic), member of CEMAC trade area and proposes some measures that can be adopted to improve their conditions and ameliorate the trade for those countries.
\end{abstract}

\section{Keywords}

Central Africa, Transit Transport Corridor for Landlocked Countries

\section{Introduction}

Central Africa, composed to the countries member of CEMAC trade area, refers to the vast, deep area enclosed by the Sahara Desert and the western part of the continent's protrusion, excluding the western part of the Great Rift Valley in East Africa. It covers an area of 5,365,000 square kilometers, with undulating terrain from north to south, including the Tibesti Plateau, the Chad Basin, the Azande Plateau, the Congo Basin, the Lower Guinea Plateau and the Lunda-Katanga Plateau, and is divided between the Sahara Desert, the Sudanese steppe and the tropical rainforest belt. And the nature of the economic activities 
and their qualities services sectors, is based on many factors that determines the market size and his dynamic of the services provided [1].

Diamond, copper, manganese, cobalt, gold, uranium, tin, radium, niobium, tantalum and iron are among the most important minerals in the world, and those countries have a huge estimation capacity of those natural resources, rich in tropical forests, producing palm oil, palm kernel, rubber, cocoa, etc. The economy is mainly based on agriculture, followed by mining, and is mostly low-income. This is because, the poor condition of transport network of the landlocked countries has been affected the export flows and import of those countries, such as the investigation conducted on Asian trade flows of landlocked countries there [2].

Central Africa is located on both sides of the equator, with a savannah climate in the east and a tropical rainforest climate in the west. Temperatures are above 20 degrees throughout the year. And for 6 countries of this region members of CEMAC trade zone, which facilitate the trade between them, amount those six countries, there are two landlocked countries. The landlocked countries of CEMAC trading zone are facing the same challenges as most of the landlocked developing countries around the world on the international trade aspect. One of the main factors which have been considered as the main constraints of the landlocked countries, which impact their economic development, is the difficulties of integration and access to the major market with a competitive and constant activities [3].

As stated by [3], some of the main challenges faced by the landlocked countries are the distance but also, they depend on transit passage which is under the sovereign transit country police and agreement, which doesn't allow them to have more flexibility on their participation on international shipping market.

Also, transit transport along transport corridors of the landlocked countries has not been competitive, due to the fact that, the process of this transit transport requires a procedure which needs to use a number of elements documents such as: documents for transit declarations, information systems and financial guarantees. All these elements need to be used at each step of the goods delivery process along the transport corridors and the poor management of this procedure is one of the cause of delays.

The dependence of landlocked countries to the transit countries for the maritime shipping international trade is one of the main factors of their trading level vulnerability as started by [4].

Inefficient gateways in these transport corridors, the entire logistics cost is spent on gateway expenses. We can analyze two reasons for the inefficiency of the port of Douala: port congestion and the distribution of goods for inland transport.

The level of total trading export and import between landlocked countries and seacoast countries is very huge, around 30\% for landlocked countries compared to the others countries [5]. 
The capacities productivity of landlocked countries economic is restricted and dependent of transits countries economic and financial situation [6].

The economic in landlocked countries can be boost as suggested by [8] Recent OECD, by in investment on the goods infrastructures transport networks system to connect the countries to the sea ports by road, rails links, airports) [7].

Accessibility to major markets of landlocked countries has always been one of the biggest constraints for the economic and social developing of those countries [3].

The distance and high-cost transportation costs are responsible of the less capital export average of the landlocked countries than seacoast countries [3].

As is the same situation around the world faced by landlocked developing countries, all of them are completely depending on their transit neighbors' infrastructure and administrative procedures to transport their goods to from port to the countries or vis versa. In many cases transit neighbors of landlocked developing countries are themselves developing countries, often of broadly similar economic structure and beset by similar scarcities of resources.

The transport networks infrastructures of Chad and the Central African Republic has been neglected for many years now and this situation has seriously negatively impacted the transport corridors continuously and impact their trading revenue and status with the rest of the world, which makes both countries significantly less competitive and attractive for foreigner investment even the countries have many opportunities of business such as natural resources. That situation has even made the two countries through their Ministries of Trade to implement some programs and various reform measures to improve their economic and increase the level of trade exchanges between them first and the rest of the world. Thus, why it was signed for example in 1999 a bilateral Cameroon Chad agreement signed that improved the communication with international markets should be considered and that poverty reduction would require the construction of new transport infrastructure and the development of complementary means of transport.

\section{Methodology}

The methodology applied for our paper here is based on deductive approach, as presenting the factors of challenges faced by the landlocked countries of CEMAC countries member and some potential's factors of solutions. as is employed the qualitative method based on books, previous literature papers, conferences, magazines, official's website etc., from the literature reviews give us some results factors.

\section{Analysis and Results}

\subsection{Port Congestion}

Even though the port of Douala is well organized in terms of planning and executing the expansion of the port, it still faces some problems. The Douala Port 
Authority provides economic operators (shippers or consignees) with 11 days to complete all administrative procedures related to shipments from the port. It was noted that most economic operators do not speed up the process of settling with their cargo. In addition, transit traffic included very slow release of cargo from the port of Douala, with the required cargo having seven documents, which were handled by three separate offices.

The prolonged stopping of cargoes has led to a number of undesirable consequences such as increased costs, increased stacking of cargoes in the port and ultimately congestion in the port, leading to a reduction in the storage capacity of the port and increasing the logistics costs of the system. In addition, there are truck blockages in the port due to insufficient parking in areas inside and outside the port. After all this huge a stuff procedure the traders of landlocked countries need to deal now with the transportation cost drive from the sea port of the transit countries to the destination is so high as a cost are consider as one of the factors that reduce the volume of trade of those countries, according to the world trade [8].

\subsection{Inland Transport Cargo Allocation}

Inefficiencies in transport corridor gateways can also be caused by inadequate rules for quota transport and cargo distribution for transit traffic. The objective of quota transport is to guarantee a share of demand for trucking companies in each country. The shares are $65 \%$ and $35 \%$ for Chadian and Cameroonian operators (Douala-N'Djamena transport corridor), and 60\% and $40 \%$ for Central African Republic and Cameroonian operators (Douala-Bangui transport corridor) respectively. On the other hand, I observed that Cameroonian truckers still dominate; the measures for the distribution of freight are not yet perfect. Cameroonian transport companies receive a significant share of the Douala-Banjamina transport corridor, with $65 \%$ and $71 \%$ of the Douala-Bangui transport corridor, respectively.

\subsection{The Major Inefficiency Inland Transport Transit Corridors Factors for Landlocked Countries in Central Africa}

\subsubsection{Organization of the Trucking Industry}

In the transport corridor, the road transport industry is made up of two types of hauliers or truckers: informal truckers and formal truckers.

\subsubsection{Informal Truck Drivers}

The informal sector of trucking is made up of truck owners who provide services to public and private operators. These types of truckers usually have limited training and in practice they do not use modern management techniques. They operate with older fleets and tend to overload trucks, thus encouraging unofficial payment (bribery) officials to release the goods and move on. Overloaded trucks can damage road infrastructure and create unfair competition to official truckers through unofficial truckers, as they offer lower transport prices than official truckers. 


\subsubsection{Regular Truck Drivers}

The formal sector of freight transport consists of well-organized truck drivers and indeed other activities such as freight and import/export to support transport activities. They are professional companies that use modern management techniques with newer fleets. The load is fixed at 25 tons for a two-axle truck and 30 tons for a three-axle truck. Due to the influence of the informal truckers on the logistics system, the regular truckers cannot apply the same transport prices as they do; they can only increase their transport prices due to their higher operating costs (maintenance costs) being higher.

\subsubsection{Rail Transport}

Rail transport to either of the landlocked countries in Cameroon is cheaper than road transport, which means that with an expandable rail network, rail transport has an advantage over road transport in terms of transport prices and cargo delays. However, there is now no rail network directly linking Douala to N'Djamena or Douala to Bangui. Today the rail network between Cameroon and Chad is $884 \mathrm{~km}$, while the rail network between Cameroon and trucks is only $602 \mathrm{~km}$.

\subsubsection{Market Structures}

Freight companies in the trade transport corridor are limiting competition, and under this unhealthy competition, consistently lower prices are making the quality of service worse. In a competitive transport market, transport prices depend on logistics costs or the balance between supply and demand. It is also related to the type of goods, road infrastructure, informal payments and load factors.

Traditionally, transport prices should be set by market regulation, with shippers negotiating transport prices directly with freight companies. With regard to the freight industry, we note market distortions and a shortage of specialist logistics service providers. Freight companies can only make a profit on high-value goods: manufactured goods, oil and mining equipment, for example. Less profitable goods such as food and cement are transported less, making the market increasingly unbalanced.

\subsubsection{Many Checkpoints and Bribes}

There are defined checkpoints on each transport corridor, 8 checkpoints Doula-N'Djamena (7 in Cameroon and 1 in Chad) transport corridor and 6 checkpoints in Douala Bangui transport corridor (3 in Cameroon and 3 in trucks), managed by representative authorities such as: customs, police, gendarmerie, National Directorate of Freight. However, the presence of illegal checkpoints on these transport corridors has been observed. These additional checkpoints and controls on the roads of landlocked countries cause delays in processing these controls wasting wasted time and increasing costs due to informal payments. Although this relative cost is small, it reduces the profitability transporters enforce an increase in transport prices to recover these informal payments.

With regard to bribes, in general, informal truckers often pay more bribes 
than formal truckers because of their low-powered negotiations when they are surprised to carry overloaded cargo or overloads.

\subsubsection{Poor Customs Information Communication}

Border logistical operations on these transport corridors encountered some problems. Analyzing those problems, due to the absence of customs, I would show the ineffective interconnectivity of encounters and the lack of a cargo tracking system.

So far, the national customs services of Cameroon, Chad and Central African Republic are not interconnected, even together with their efforts. A good interconnection of the customs services between these countries must contribute to a better management of statistics as well as to a good coordination of information on transport corridor processes. The implementation of this measure should facilitate the possibility of informing economic operators of their transport processes, timely and qualitative information should be available to all parties to the transport of goods. In 2009, Cameroon Customs introduced GPS, which is used to track all vehicles and goods on the transport corridor to their destination in these landlocked countries. As of 2014, the GPS is being fixed on the trucks. The GPS is therefore an obligatory transit freight for the restoration of goods. Even if the GPS meets some of the objectives of the Cameroon customs service, the operator does so while the agent still complains that this constitutes a supplementary cost and step in the transit clearance process. Nevertheless, the uniformity of the GPS is not enough; fixing it can take many days before illegal payments appear. The time and money wasted constitutes a less efficient transit process and ultimately more costly.

\subsubsection{Slow Clearance}

Inland terminals and customs clearance take up a significant proportion (over $50 \%)$ of the total logistics costs. So far, the process of final clearance does not operate smoothly and there are time delays. The time needed to cross the border is supposed to be one day, but some truck drivers take two to three days.

\subsubsection{Transport Safety Is Not Guaranteed}

Considering the number of accidents and losses, the issue of transport safety is becoming increasingly important for life and property. The weakness of this area is due to the indifference of the authorities responsible for road safety and the non-enforcement of road rules. This is mainly due to the lack of financial resources.

\section{Recommendations for Improving Transit Transport Corridors for Landlocked Countries in Central Africa}

Transport plays a very important role in the trade facilitation process, whether national, regional or international. Given that transport and trade are interlinked, the Bank has made trade facilitation an imperative, recognizing that a country's economic prosperity is sought through trade with overseas. The aim of 
transport and trade facilitation is to simplify procedures and reduce transport costs by improving transport chains seeking mutual benefits between operators, regulators and traders so that countries can develop. To achieve this, countries should take a number of measures to facilitate exchanges between them.

\subsection{Trade Facilitation}

The concept of trade facilitation was introduced in Singapore in 1996 at the end of the WTO Ministerial Conference. Trade facilitation is defined as the facilitation of trade between countries for the purpose of promoting or simplifying trade, enhancing logistical conditions and eliminating any type of physical or material non-physical barriers which is a factor of trade and economic growth in the sense that it allows for the simplification of process times associated with the movement of goods by reducing costs.

Specifically, trade facilitation measures are:

1) Simplification of trade policy delays that promote cost reduction and elimination.

2) Road transport-based modes of building infrastructure are most often used for the transport of goods in transit (about 80 per cent) for landlocked countries.

3) The implementation of measures to facilitate transport and trade requires human and financial resources to develop the road network connecting the country.

The capacity of the port of Douala is insufficient (with 65,000 tons of vessels) and the Cameroonian government needs to build another port, the port of Kribi, to make it possible for large ships from West Africa to also pass-through Cameroonian ports. While the two ports are complementary, the port of Douala could focus on the domestic market, while the port of Kribi would have a more regional focus, such as serving landlocked countries at the end of the Kashi-Chad pipeline, and Kribi would be a gateway to landlocked countries (Chad and the Caribbean) and other neighboring countries (Congo, Equatorial) Guinea and Gabon). The construction of the port of Kribi will be a major economic boost.

Cameroon and its two neighboring landlocked countries will be connected to the trade market transport corridor mainly through two transport corridors. However, now with the development of the new port of Cameroon (Port Kribi), both countries will have the option of using two transport corridors. The performance of each transport corridor must be considered, although performance is a result of the infrastructure, services and systems which affect the volume, cost and time of transport on the transport corridor.

\subsection{Possible Measures to Improve Transport Access}

Trade and transport between Cameroon and its landlocked border countries is hampered by many factors along the transport corridor, which take into account the length of cargo delays the performance of inland transport, the non-competitiveness of transport services, informal procedures and payments. 
It is therefore necessary to develop solutions and strategies for moving goods to effectively facilitate transport services along the entire transport corridor. These objectives can only be achieved in the public and private sectors where the countries concerned work together to ensure improved quality services. The reduction of bottlenecks in transport corridors is achieved through the following actions.

\subsection{Improving the Efficiency of Customs Clearance and Transit Procedures}

In order to improve the efficiency of customs clearance and transit procedures, it is necessary to strengthen transit transport countries by improving these customs interconnection systems to achieve this, enhanced investment in ICT capacity will be essential Infrastructure development, the development of logistics centers, must be able to coordinate cross-border procedures. With regard to ICT, enhancing the use of ICT by creating appropriate databases containing transport information and easy access to cargo transport in the process of all stakeholders.

\subsection{Improving the Efficiency of the Transport Process}

Improving the efficiency of the transport process will require a number of initiatives:

1) Improving the efficiency of the transport infrastructure.

2) The expansion of the railway network from Douala to N'Djamena and from Douala to Bangui must follow the expansion of the truck fleet. For road transport, the improvement of transport corridors transport road infrastructure should be done by asphalting unpaved roads, building bridges and repairing road deterioration.

3) Improving the efficiency of logistics services.

4) In order to improve the efficiency of logistics services, all actors relative to the operation of transport and trade (freight forwarders, freight companies, port authorities, customs, police, etc.) must be able to regulate their services. Ensuring the professionalism and the improvement of the management capacity of these actors will require: training courses related to the professionalization of the management of logistics services in relation to the activities of truck drivers and freight forwarders.

\subsection{Improving the Structure of the Freight Market}

Improving the structure of the freight market will require the following measures: import and export controls on the occupation of hauliers or truckers, encouraging financial institutions to give credit to hauliers to invest in new vehicles, encouraging small truckers and informal truckers to renew their fleets through short- and medium-term financial credit measures, participation in reducing vehicle operating costs and limiting taxes on the factors fuel. Private truck-owning companies must create common initiative groups to improve their 
actions. Given that everyone's stake will be in the game, respecting the provisions of this profession will be more effective and they will be in front of more credible financial institutions are currently asking for bank loans.

\subsection{Strengthening Administrative Enforcement of Transport Corridors}

Administrative enforcement along transport corridors will be achieved by eliminating informal checkpoints created along transport corridors, reducing the practice of corruption control units in checkpoints and weighing centers stations, creating appropriate transport corridor management bodies and strengthening enforcement actions along transport corridors for traffic facilitation. In short, in order to facilitate transit trade flows, harmonization and the importance of simplifying the procedures required for the movement of goods from one country to another, particularly with regard to regulations, customs, banking and insurance, are essential.

\subsection{Safeguarding Transport Safety}

There is a need to consider regulatory measures aimed at reducing accident rates along transport corridors, to allocate sufficient funds to safety programmer, to manage traffic and to ensure safety.

\subsection{Increase Financing for Road Network Construction}

Despite the large number of foreign investors in road infrastructure, the governments of the three countries should encourage public and private transport infrastructure financing, construction and development partnerships to complement publicly funded investments. It is also necessary to maintain adequate and timely rehabilitation of the road network and to reduce financing in the long term. All these responses will reach the coastal countries and the countries of the two landlocked countries can present important gains in terms of reduced cargo delivery times as well as lower costs. In addition, it is also necessary for these countries to consider the integration of other transit transport as international transport traffic.

\subsection{Accession to and Implementation of the TIR Convention}

The TIR (Transports Internationaux Routiers) Convention refers to the Convention on International Road Transport, which was created in 1975 and entered into force in 1978, and provides that road carriers carrying containers with a TIR manual may travel from point of origin to destination without inspection, payment of taxes or deposits under customs seals. The TIR traffic system is also an intermodal system and constitutes a major facilitator of both transport and trade, and is regarded as a best practice transit transport at regional and international level.

TIR is available in two forms: paper and electronic. The paper is being used by 
the transporter at different points along the transport corridor where travel is controlled, while the electronic document is managed in an internet-based application from the country of transit (origin) up to the final country. The TIR convention allows for the temporary suspension of customs duties and VAT on cleared goods at the designated customs area of destination. The TIR system focuses on a win-win partnership in terms of cost and time between private and public operators, the reliability and efficiency of which are the hallmarks of a successful transit procedure.

However, none of these landlocked Central African countries has yet acceded to the convention.

Increasing the benefits for Cameroon as a transit country.

The benefits of Cameroon becoming a transit country for its neighboring landlocked countries the construction of the new port will bring direct benefits to the economy. Being a transit country has its own benefits, which are mainly reflected in the following areas.

1) Political benefits as a transit country Cameroon will play a regional leadership role and will expand its added value as trade with its neighboring landlocked countries will have opportunities for Cameroonian public and private companies, such as railway companies, transport operators or truck drivers.

2) Increased direct revenues. The arrival of new ports will increase the flow of goods and so increase the cost of using the infrastructure relative to road transport services, railways etc. These costs are: the transit fees normally charged at the border and the fuel tax paid by all truck drivers using the transit countries.

3) Increase in indirect costs. Without the increase in indirect costs, the return of the increase in direct revenues would not have occurred. These indirect costs are: the spread of sexually transmitted diseases by drivers, air pollution, noise, traffic accidents and loss of goods.

The economic impact of the port of Kribi on landlocked countries.

These countries would be a new beginning compared to the difficulties of these countries encountered during the execution of operations on the Douala-N'Djamena transport corridor in Douala Bangui, as a destination for landlocked countries with poor quality and inefficient services between the port of Douala and the port of Douala, which do not provide integrity and security in the supply chain. This is the result of over-regulation, the creation of unregulated transit practices, such as encouraging informal payments. Given that the Port of Kribi will be a priority port for the transit of goods, these countries are aware of the challenges they will face, so they may make such a challenge to turn to reforms in the first place. Finding ways to map out a new system, because whatever they are the most important thing is that the reforms make their transit systems more efficient and less corrupt.

\subsection{Strengthening Mutual Trust and Cooperation between Countries}

In the current situation, there is a very clear and mutually beneficial relationship 
between Cameroon and its landlocked countries. Therefore, a mutually agreed plan for information sharing between several countries is a win-win basis and requires mutual trust between the two parties. Without a minimum level of trust, trade and transport cannot be successfully completed. Trust and credibility built on a good relationship will be the result of the expansion of trade and transport between countries and heavily influence their economic growth.

From all the recommendations mentioned previously, we can assume that sometimes the reality is not reflecting the exact research context and we need to adjust it. Also, the major weakness of all this recommendation is that at least two countries with different political vision and goals need to cooperate for this transit cooperation to work, which is not easy in reality as we think.

\section{Conclusions}

Through the problems that exist, Chad and the Caribbean, although participating in world trade, they are still far behind the world level. It is for this reason that transport links along the routes need to be improved in order to create trade competitiveness on regional and international markets.

The landlocked countries of Central Africa would also like to be considered countries with emerging economies. Their trade with international markets is growing year on year, given that the world economy is growing year on year. Infrastructure development or practical applications on transport corridors need to strengthen and improve communication with the world market. In the face of international competition, some countries have taken a number of measures to improve international trade and economic growth, such as the landlocked countries of West Africa. However, it is important to note that other countries, such as the landlocked countries of Central Africa, will certainly notice their economic growth, but at a low rate.

It is essential to implement measures that affect economic growth, taking into account the reduction of transport costs. In addition to the cost aspect, it is also important to consider the extension of time, volume, reliability and improved safety of the performance of transport corridors.

\section{Conflicts of Interest}

The authors declare no conflicts of interest regarding the publication of this paper.

\section{References}

[1] van der Marel, E. (2012) Determinants of Comparative Advantage in Services. FIW Working Paper No. 87, May 2012.

[2] Grigoriou, C. (2007) Landlockedness, Infrastructure and Trade: New Estimates for Central Asian Countries. Policy Research Working Paper 4335, World Bank. https://doi.org/10.1596/1813-9450-4335

[3] Faye, M.L., Mcarthur, J., Sachs, J.D. and Snow, T. (2004) The Challenges Facing Landlocked Developing Countries. Journal of Human Development, 5, 31-68. 
https://doi.org/10.1080/14649880310001660201

[4] Gotcheva, K. (2004) Landlocked Countries: Opportunities, Challenges, Recommendations. p. 1.

[5] Limao, N. and Venables, A.J. (2001) Infrastructure, Geographical Disadvantage, Transport Costs, and Trade. The World Bank Economic Review, 15, 451-479. https://doi.org/10.1093/wber/15.3.451

[6] United Nations (2013) The Commitment. Linking Landlocked Countries to Global Opportunities. Special Future: Gyan Chandra Acharya, Unlocking the Potential of Landlocked Developing Countries, p. 3.

[7] United Nations (2003) Economic and Social Commission for Asia and the Pacific. Landlocked Developing Countries Series, No. 1. Transit Transport Issues in Landlocked and Transit Developing Countries, New York, p. 5.

[8] McQuaid, W.R., Greig, M. and Smyth, C.J. (2004) The Importance of Transport in Business Location Decisions. Napier University, p. 4. 